Table 3. Protein value of fish treated by modern and traditional methods

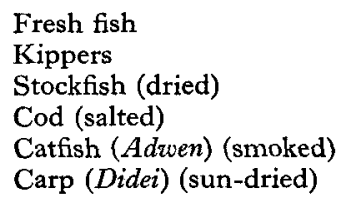

$\begin{array}{lc}\text { Origin } & \text { N.P.U.(op) }(\%) \\ - & 90^{*} \\ \text { U.K. } & 8 \mathrm{I} \\ \text { Norway } & 91 \\ \text { Norway } & 69 \\ \text { Ghana } & 65 \\ \text { Ghana } & 57\end{array}$

*Value reported by Miller (1956) for carefully dried fish proteins from both oily and white fish of marine origin; values obtained for the biological value of the proteins (concentration in diet not stated) of freshwater fish range from 72 to $89 \%$ (Kuppuswamy, Srinivasan \& Subrahmanyan, I 958).

could be nearly doubled by improvements in processing. This example illustrates the need for the application of food science and technology in the improvement of traditional and in the introduction of new methods of food preservation and storage.

\title{
REFERENCES
}

Grant, F. W. (1955). Nutrition and Health of Children in the Gold Coast. Chicago: University of Chicago Press.

Kuppuswamy, S., Srinivasan, M. \& Subrahmanyan, V. (1958). Spec. Rep. Ser. Indian Coun. med. Res. no. 33.

Miller, D. S. (1956). F. Sci. Fd Agric. 7, 337.

Platt, B. S. (1953). In Handbook of Tropical Dermatology and Medical Mycology. Vol. 2, p. 1480. [R. D. P. Simons, editor.] Amsterdam: Elsevier.

Platt, B. S. \& Mayer, J. (1958). Report of a Foint FAO/WHO Mission to Ghana.

Platt, B. S. \& Miller, D. S. (1959). Proc. Nutr. Soc. 18, vii.

\section{Some African problems}

By F. Aylward, Department of Chemistry and Food Technology, Borough Polytechnic, London, S.E.I

\section{Introduction}

This review must be selective both in the geographical sense and in the problems chosen for discussion. There are wide differences between the various countries and territories of Africa, but there are many problems common to those regions which can be regarded as economically underdeveloped. Such regions are characterized by a social pattern founded on village life with agriculture the great (and often the only) source of livelihood.

Medical opinion is unanimous that the high death rates in these agricultural communities must be traced in part to poor diets, and in particular: (I) to deficiencies in the total food supply (especially during the so-called hungry seasons-after poor harvests); (2) to deficiencies in food quality-notably shortages of protein and perhaps also of certain vitamins (such as ascorbic acid or members of the B complex). In effect ( $\mathrm{I}$ ) and (2) summarize the basic food problems of Africa, but further problems arise immediately remedies are sought. 
Many writers on world food problems and many workers in the field have been concerned primarily with methods for increasing agricultural production, by bringing more land under cultivation and by improvements in the fertility of soils through irrigation schemes and the application of fertilizers (cf. Aylward, r960a,b). On the other hand, it seems obvious that such development projects, however important, should concede second place to programmes designed to ensure that the existing crops (as grown) and animals (including fish and wild life) should be used to the fullest possible extent as foods for man. In such conservation programmes the applications of food science and technology are all important.

\section{Contributions of food science and technology}

The potential contributions may be summarized as follows.

Direct effects

(I) Improved storage methods will increase the total foods available.

(2) Improved preservation and processing methods can increase the total amount of quality foods or can lead to the raising of quality (for example in respect to protein and vitamins) of existing foods, or both.

(3) Special processing methods can transform the components of crops, at present not utilized by man, into human foodstuffs.

\section{Indirect effects}

(4) The growth of food processing industries can contribute to the economy of a country as a whole or to that of specific regions.

(5) Improved processing techniques (combined with appropriate agricultural production policies) can reduce the necessity for food imports, leading in turn to the possibility of using the money saved for the importation of machinery, equipment and fertilizers, with a view to further increases in agricultural production.

(6) Improved processing methods could likewise increase the volume of exports of surplus products.

(7) Even small changes in processing methods may profoundly affect household and commercial practice and may liberate the housewife and others in part from timeconsuming tasks, so that leisure may be increased and labour made available for other more productive purposes.

Several other potential contributions of food science and technology could be discussed: it is evident that for the framing of a national food policy in an African country information is required on the composition and nutritive value of the foods as grown, as processed and as eaten and of the quantities of different foods that are available or can be made available, in relation to the needs of the population.

The direct effects of the application of food technology (as listed above) may be summarized as a nutritional contribution to both total food supplies and food quality. The indirect effects, largely economic and social, could lead to increased productivity and increased purchasing power for foods. Some of the points (1) to (7) will now be considered, 


\section{Direct contributions}

(I) Food storage. Many observers now recognize that in Africa and elsewhere a very high proportion of the potential food supplies, whether of plant or animal origin, is not used and that the avoidance of waste should be given high priority (cf. Pirie, I960). Wastage of food can arise from three main sources (a) losses in the field as a result of virus and other diseases and the action of insects and other pests, (b) losses of stored food because of deterioration brought about by heat and humidity or by pests (c) losses in the home or restaurant (larder, cooking or plate losses). It is extremely difficult to obtain reliable estimates for (a), (b) and (c) in any country; suggestions have been made that the losses may reach high proportions, e.g. $10 \%$ or more from each source or $30 \%$ or more from all sources. In an agricultural society the loss from (c) may be low, but in tropical and semi-tropical countries losses from (a) and (b) may be very high (see for example Nicholls, I95 I; Oser, I956, p. 253; Pirie, r960; Aylward, r960a,b; (The) Nutrition Society, 196r).

The control of pests which attack crops (and parallel work on the control of diseases in domesticated animals) is now the subject of intensive agricultural research in many countries, and field trials have taken place in several parts of Africa. Storage problems come within the domain of food science and technology and, although there is now a corpus of knowledge about storage in temperate climates, much remains to be learnt regarding tropical zones. The very conditions which enable many sectors of tropical agriculture to flourish create difficulties in respect of food storage and preservation-on the one hand because of the wide variety of insects and other pests and on the other because heat and seasonal humidity provide conditions for the rapid decomposition of foods. Thus, reports from some parts of Africa state that grain on sale in local markets may contain $50 \%$ weevils and that dried fish may lose $20-50 \%$ of its value through the action of insects.

Food storage is a theme that runs throughout recorded human history and many accounts are available of successes achieved in the ancient world (e.g. the 'magazines' or storehouses in the palaces of Crete; the granaries of the Pharaohs). Anthropologists and others who have carried out detailed surveys of life in African villages have stressed that the granary (so essential for survival) may be regarded as 'man's most private and personal possession' (Fortes \& Fortes, 1935). They have pointed out that some communities have devised excellent receptacles and adequate techniques for storing different types of food, so that grain and groundnuts taken from the granaries or storage baskets after I year were in excellent condition and that even root crops and legumes (most sensitive to moisture and insects) can be stored for a year. Thus, the traditional methods used may be effective in some areas, but may be unknown elsewhere.

In some major African cities modern storage techniques have been introduced; if capital is available there is no great difficulty in finding an individual food engineer or industrial concern capable of designing and operating commercial cold stores or storage warehouses. In many regions, however, the real problem is not of large-scale storage, but rather the design of relatively small units, for a family or a village community or for a group of villages. Such units would ideally be of simple construction 
and made of materials readily available cheaply and locally so that they could be built or installed through self-help or community development schemes. The investigation of traditional methods currently used with a view to spreading information regarding reliable procedures or of improving on them could well be a rewarding research project with far-reaching consequences.

(2) Food preservation and processing. Unless refrigeration is available, some form of processing (as distinct from simple storage) is required for all animal foods and for many vegetable foods. In the metropolitan areas of Africa with their increasing populations there will undoubtedly be scope for factories on the European and North American models. In many country areas important contributions can come through the development of relatively small multi-purpose units as the basis of local (perhaps even seasonal) industries with efficient yet simple machinery, with low capital and maintenance cost and the minimum requirements for technical supervision. There is evidence (e.g. the groundnuts scheme in Tanganyika) that the bulldozer and the large tractor can have a disruptive effect not only on tropical soils but on agriculture and community life generally, whereas smaller agricultural projects, based on the realities of a local situation, have been successful. So too it would appear that smallscale food processing units, still highly effective in many parts of continental Europe although disappearing in the United Kingdom, should be given a high priority.

Several examples may be quoted of the successful introduction of small-scale plants to operate under tropical conditions in Ghana and other parts of Africa. Thus, some hundreds of plate mills (costing less than $£ 200$ each) have been set up in Ghana and have proved of value for cereals and other crops (D. J. Greig, 1959, unpublished report, University College of Ghana); a bottling and canning plant (for tomatoes and fruits) with auxiliary plant for juice concentration shows distinct promise; a pilot plant has yielded a stable fishmeal of good quality. Production units such as these (operating perhaps in conjunction with Agriculture Producer Co-operatives) may well play a major role in the rural economy of developing countries. Some observers would go further and suggest that the most speedy improvements in some regions could come from the application of the methods and equipment used in an English village by Women's Institutes.

(3) Special processing methods. It is recognized that certain crops cannot be eaten directly by man without some form of pretreatment-sometimes simple cooking procedures to remove or destroy indigestible or poisonous components, for example the removal of hydrogen cyanide from cassava (or manioc) (Nicholls, I95 I Aylward, I953). Recent investigations (Miller, 1961) suggest that correct treatment may make available tropical legumes and other crops normally regarded as unsuitable for human use.

Other processing techniques have as a primary aim the concentration of edible material or of some particular fraction (such as protein); since some of the major nutritional problems of Africa arise from the low protein : carbohydrate ratio in the diet, projects for the preparation of protein-rich foods from plant sources (such as oilseeds) are of first importance (see Cuthbertson (I96r), Wokes (rg6r) and reviews such as those by Pirie (1959, I960), Dean (1953) and Altschul, (1958)). 
Indirect contributions

The indirect effects of developments in food processing are frequently overlooked; they may be obscured in a heavily industrialized country, but may be of special importance in tropical and semi-tropical Africa where agriculture is a prime source of wealth and such industries as exist are frequently based on indigenous agriculture. The food industries are an essential part of the industrial pattern in any country; they must be considered against the broad picture of economic and social developments; they contribute to such developments and in turn are affected by them.

The indirect effects of advances in food processing have already been summarized and space does not permit of detailed comment. It may, however, be well to stress the enormous expenditure of time and energy required in certain African communities for food preparation and especially for the manual grinding of grain. The low-cost plate mills, to which reference has already been made, illustrate the marked and continuing success that can follow the introduction of a relatively simple and relatively cheap piece of machinery that can reduce the necessity for hard labour, speed up processing and liberate people for other tasks--and all without any major change in or disturbance of the pattern of agriculture and industry.

\section{Conclusions}

Many of the food and nutrition problems of Africa have been considered in earlier symposia or meetings of this Society (e.g. (The) Nutrition Society, 1956). There has been general agreement that improvements in nutrition will require a co-operative effort of workers trained in different disciplines including medicine, agriculture and food science and technology, and that co-operation is required on an even wider basis with those concerned with different facets of education (including the allimportant 'extension' sector) and with economics and the social sciences. Plans for food storage, for example, cannot be considered only in terms of adequate techniques; they will be dependent on economic and social factors also.

The potential contribution of food science and technology has not always been fully appreciated in Africa (and elsewhere), but has received in recent years increasing recognition in programmes of aid to developing countries.

I spent some 5 months in Ghana on an assignment sponsored by the Nutrition Division of the Food and Agriculture Organization of the United Nations in conjunction with the Ministry of Agriculture of Ghana. I wish to acknowledge my indebtedness to FAO and to the Government of Ghana for the facilities provided; the views expressed in this paper are, however, my own.

\section{REFERENCES}

Altschul, A. M. (editor) (1958). Processed Plant Protein Foodstuffs, New York: Academic Press Inc, Aylward, F. (1953). Proc. Nutr. Soc. 12, 48.

Aylward, F. (1960a). Food Manuf. 35, 6r.

Aylward, F. (x $960 b)$, Food Manuf. 35, 107, 
Cuthbertson, W. F. J. (1961). Proc. Nutr. Soc. 20, 122.

Dean, R. F. A. (1953). Spec. Rep. Ser. med. Res. Coun., Lond., no. 279.

Fortes, M. \& Fortes, S. L. (1935). Africa, 9, 237.

Nicholls, L. (1951). Tropical Nutrition and Dietetics, 3 rd ed. London: Baillière, Tindal \& Cox.

Nutrition Society. (1956). Proc. Nutr. Soc. 15, I-40.

Nutrition Society. (196I). Proc. Nutr. Soc. 20, I-24.

Oser, J. (1956). Must Men Starve. London: Jonathan Cape.

Pirie, N. W. (1959). Annu. Rev. Pl. Physiol. 1o, 33.

Pirie, N. W. (1960). Discovery, p. 374.

Miller, D. S. (1961). Proc. Nutr. Soc. 20, xxi.

Wokes, F. (1961). Proc. Nutr. Soc. 20, I17.

\section{India's food problems}

By Frank Wokes, Vegetarian Nutritional Research Centre, Garston, Watford, Herts.

India, one of the four major regions in which enormous populations are crowded into confined areas, shares with adjoining China the unenviable reputation of enduring the world's worst famines and widespread malnutrition. North-western Europe and North America contain the other two major regions whose help India seeks.

Religions in India, China and other parts of the Far East advocate the principle of ahimsa (non-violence). It forbids the killing of animals, hence influences diets and is an important factor in India's food problems (Russell, 1954). Ahimsa originated 2500 years ago in the teachings of Buddha and other Indian religious leaders. Their dietetic principles were brought to Europe by Pythagoras, and passed down through the ages by the Essenes, Albigenses, Trappists and other religious groups to presentday vegetarians who consume no animal food except eggs and dairy produce. The United States of America contain several million vegetarians, representing about $2 \%$ of the population (Gunther, 1947). The United Kingdom contains less than 100000 vegetarians, about $0.2 \%$ of the population. These few British vegetarians hope to help with food problems in India where the population is largely vegetarian.

Many nutritional surveys and studies have been made by the outstanding pioneer Sir Robert McCarrison and his successors at Coonoor Nutrition Research Laboratories and by workers at Bombay, Calcutta, Delhi, Mysore and elsewhere. At Buddh Gaya, Benares, Delhi and other places India also has centres of past and present religious activity that influence its dietary customs. In Delhi a new university is being established by Vishva Ahimsa Sangh (World Fellowship of Religions) to promulgate the principles of ahimsa. It is proposed that there will be there a vegetarian nutritional research centre that will apply these principles.

Nutritional studies in India reveal serious deficiencies not only of calories but also of vitamins and other nutrients, especially protein. The average daily intake of total protein in India is only about half that in the U.K. and U.S.A. The animal-protein intake in India is only about a seventh of the U.K. intake and only about a tenth of 